\title{
Touchstones: Editorial Introduction 23(2)
}

\author{
Ruth Fletcher ${ }^{1}$
}

Published online: 29 August 2015

(C) Springer Science+Business Media Dordrecht 2015

This issue of Feminist Legal Studies (FLS) picks up the conversation between feminism and legality as our contributors think about gender, sexuality and race; kinship and care; courts and diverse legal subjects. We present a range of submissions - papers, an interview and reviews - which critique the doing of law in different jurisdictions-South Africa, the International Criminal Court, England and Nairobi-and reflect on the scholarship which touches and animates feminist critiques. Feminist concepts, abstract and concrete, continue to provide important touchstones for finding a way through the challenges of transformative struggles. In this introduction, I draw on Editorial Board discussion to outline each original contribution and consider some of the touchstones encountered along the way.

Bonthuys (2015) article "Gender and Race in Judicial Appointments in South Africa" examines a "local manifestation of the global interest in women judges" as she considers how the debate about transformation of the judiciary plays out. Her analysis critiques the public debate over judicial appointments in South Africa by focusing on the arguments of the Judicial Service Commission (JSC), media commentators, and gender activists over a three year period. She argues that gender and race are being cast in problematically exclusive, non-intersectional terms. In these circumstances, the prioritization of racial transformation of the judiciary has the effect of displacing the need for gender transformation and the occlusion of the need for better representation of Black African women in particular. She also argues that gender transformation is too narrowly focused on the inclusion of greater numbers of women. The judicial and legal institutionalized culture (Albertyn 2014,

Ruth Fletcher

r.fletcher@qmul.ac.uk

1 Department of Law, Queen Mary University of London, Mile End Road, London E1 4NS, UK 
276), which perpetuates gender and racialised inequalities, will not be sufficiently challenged without the appointment of feminist judges.

Along the way, Bonthuys provides a rich account of key interventions in the debate, including over the appointment of Mogoeng Mogoeng as Chief Justice of South Africa. Her article is also important for the way it draws out the significance of affect and rhetoric in these public debates. The resentful tone of the public debates over accusations of 'dumbing down' of judicial appointments indicate for her the on-going lived effects of apartheid and racism, and the difficulties in achieving meaningful transformation. As Bonthuys says, conversations about race, gender and professional merit in judicial appointments are "embedded in centuries of racial discourse, in which some terms have racialised or even racist connotations which are difficult to articulate, but viscerally experienced by participants." This reader found herself thinking about the hidden energy involved in generating and sustaining critique in this context, a kind of commitment which Douglas, Jivraj and Lamble have discussed as the "liabilities of queer anti-racist critique" (2011), labour which requires willfulness (Willmington 2015), even as it is disparaged.

In "International Criminal Law as a Site for Women's Rights? Challenges, Possibilities, Strategies", Grewal (2015) picks up this concern with the spaces provided by courts and judicial appointments for feminist critique. She reflects on the challenges that arise for feminist activists in engaging with the International Criminal Court (ICC), and International Criminal Law (ICL) more generally on gendered harms, as this court enters its second decade of existence (see further Buss 2009; Lemaitre and Sandvik 2014). Grewal identifies three problems with the way that ICL has responded to efforts to get it to recognize the scale and gendered nature of violence. The first concerns the distinction between rape in war and rape in peace, and its reinforcing of the fantasy of equal autonomy in heterosexual relations. The second concerns the way that exploitative practices within 'ordinary' marriages become acceptable through their contrast with the aberration of forced marriage as the latter is persecuted as a crime against humanity. And the third is the way in which women's lives are reduced to experiences of sexual violence by the court's engagements with gendered arguments, at the same time as sexual violence against men remains invisible. She finds hope for moving beyond the resistance/compliance model (Kuovo and Pearson 2011) in the ways in which victims continue to insist on engagement with ICL, in Balakrishnan's theory of international law (2002), and in Otto's approach to coalitional politics and recognition of the interaction of sexual freedom and material conditions (1999).

Grewal's strategy for carving out an alternative approach would see advocates relinking a broader women's rights agenda with ICL responses to women's experiences of armed conflict. It would dismantle the associations between gendered experiences and sexual violence by providing accounts of "the social, political, economic, cultural, psychological and physical effects of war and armed combat on girls and boys", and by focusing less on the identity of the victim of sexual violence and more on the nature and consequences of the violating actions. Ultimately she wants to see a recuperation and development of sexual rights and guerrilla tactics, which identify ICL and the ICC as spaces of longer-term discursive struggle. Interestingly, her critique chimes with some of the arguments made in Heathcote 
and Otto's recent collection as reviewed in this issue. As Mouthaan notes (2015), individual chapters call for greater engagement with a feminist politics of antimilitarism and a move away from the focus on sexual violence in a collection which adopts "feelings and passions" as its organising frame.

The site of inquiry for thinking about the relationship between feminism and legality changes with the next two papers. Westwood (2015) and Dimova et al. (2015) examine how 'ordinary individuals' engage with the law of everyday life as they write wills and make care arrangements. In "Complicating Kinship and Inheritance: Older Lesbians' and Gay Men's Will-writing in England”, Westwood draws on Monk's (2011) call for further investigation of the relationship between gender, sexuality and law, and inheritance. She reflects on the significance of willwriting for a group of fifteen older (58-76) lesbians and gay men living in England because she is interested in drawing out their complex constitution of kinship. In so doing, she contributes to the queering of inheritance practices and to a repositioning of choice and obligation, and the relationship between them, as aspects of gay and lesbian kinship.

Westwood argues there are multiple factors informing decision-making in willwriting and that these decisions do not always reflect the most significant relationships, care practices or kinship formations of the testators. Her article contributes to the ongoing unpacking of the much-critiqued dichotomy between friends and family. The lived sense of obligation may attach to 'blood relatives', but may attach to friends and extended family members also, and seemed to me to have more to do with some sense of 'ownership gaps' than blood loyalty or care reciprocity. Westwood draws out the significance of doing kinship and of willwriting, while recognizing the limits of the focus on wills and asset disposal. She picks up Smart's observation that given and chosen families are fluid; they do not simply replace each other (2007). I found myself wanting to think more about why the disposal of property comes to be directed in these ways. Since Westwood's focus was on will-writers and beneficiaries, she said less about differences between the forms of property being bequeathed and how property mattered for those involved. Her call for further research into this rich terrain presents an opportunity for engaging with critical scholarship on property and belonging (e.g. Cooper and Herman 2013; Keenan 2010). In what ways have the forms of property flow that we see in inheritance and will-writing been touched by feelings of comfort and security, or discomfort and insecurity, with certain people or in certain spaces?

Like Westwood, Dimova et al. (2015) are interested in the doing of family and kinship by legal subjects in "Intimacy and Inequality: Local care chains and paid childcare in Kenya". But they focus on care of children rather than will-writing by older people, and on the 'local care chains' that are constructed along the way in Nairobi. These chains have developed as demand for home-based 'nanny' type care provision grows, often as a supplement to private nurseries and other forms of care, and with the consequent demand for cheaper, informal forms of care when nannies have children of their own. Care of children under the age of three is particularly pressing in Kenya as in other African countries where the young population is growing. Although care labour by 'nannies' and their equivalent has received international attention (Stewart 2011; Fudge 2014; Baldassar and Merla 2014), it 
has not been investigated to any significant extent in the context of East Africa. Indeed census data in Kenya does not record the people who do this kind of work, rendering it largely invisible and uncounted. In the absence of census data, the authors used novel methods in order to track the demand for nannies. They followed discussion boards on an online parenting forum for mothers residing in a middle class district of Nairobi over a period of three years and found that wages for domestic workers and childcare arrangements were the main topic of discussion.

Dimova et al. observe a tendency to look at care work by women of the Global South in terms of migration to the Global North and the constitution of "global care chains". They suggest that the emphasis on global care chains has been generated in part because it "is inspired by the lived experience of the employer-mother in the Global North", and call on feminist scholars of both paid and unpaid reproductive labour to look harder at the more commonplace, local struggles of women to organise their productive and reproductive activities. Secondly, they draw out the significance of the developmental state context for contemporary debates about 'work/family' balancing, and note the silent reliance of developmental projects on women's unpaid care work. These two angles of critique made me think about the continuing challenge of taking the global or transnational seriously without having it becomes a colonial reiteration (Darian-Smith 2015; Grewal and Kaplan 1994), and the continuing resonance of Davis's insights in Women, Race and Class (1981, 238). Feminist scholars such as Davis have long drawn our attention to the race and class dimensions of paid domestic labour in other people's homes. As Dimova et al. imply, nannies in Nairobi are hardly less deserving of academic and policy attention because they are not part of the transnational 'precareiat'. The dynamics of difference which are mobilized through practices of 'double-mothering' of some children, while the care of others is fragmented in order to achieve this 'doublemothering', seemed to speak to a need for critical 'translocal' inquiry into the organizing principles of difference in care provision.

The interview with Conaghan and Russell (2015) and the book reviews together provide a set of responses to the emergence of newer touchstones for feminist critique. The interview in particular locates Conaghan's scholarship, including Law and Gender, through Russell's reading of the text and through Conaghan's account of how she came to be interested in finding the feminine in law. The account of the question and answer session which follows, presents an opportunity to hear how Law and Gender is reframing questions of legal method, reasoning and practice for audience members. In this way, the connections between legal practice, research and education becomes more explicit as pedagogical questions generate research questions and vice versa.

The book reviews section provides readers with an entry point to five significant new texts. In reviewing Cooper's Everyday Utopias Odogwu (2015) emphasizes the theoretical and methodological contribution, which sees concepts as oscillating movement between imagining and actualization in everyday practice. As she thinks through six different sites where utopian aspirations are actually put into practice, Cooper offers utopian studies an alternative to literary visions of dream-like transformations of entire societies. Thomas (2015) reviews Rogers' Law's Cut on the Body of Human Rights, finding it a valuable intervention in debates about female 
circumcision, and a useful riposte to those who see subjects of circumcision as "hapless victims in need of rescue by stringent legislation". She comments on the book's psychoanalytical approach, its Australian focus and its engagement with critiques of the liberal subject of human rights.

Haqqani's review of Domestic Violence and the Islamic Tradition draws out the novelty of Chaudhry's reading of Qur'anic verse 4:34 and its justification of husbands' moral authority over wives (2015). Her insightful reading was produced through reflection on her own personal struggles and engagement with the different pre-colonial and post-colonial interpretations of 'Islamic tradition'. As noted previously, Moutthan's review of Heathcote and Otto's Rethinking Peacekeeping, Gender Equality and Collective Security emphasizes the significance of the 'feelings and passions' framework and summarises each of the individual chapters as they contribute to the four themes: shame, hope, danger, and silences (2015). Willmington's review of Willful Subjects (2015) by Sara Ahmed, locates this cultural, philosophical and political account of willfulness in relation to Ahmed's feminist killjoy character as she sticks and becomes trouble. For Willmington, key contributions include its capturing of the collective experience of those considered dissident and difficult as they unsettle political space and its offering "unbounded possibilities for application".

We look forward to considering further touchstones and how we might handle them in the summer of 2016 at the FLaK (Feminism, Legality and Knowledge) symposium in London, UK on 30 June and 1 July and in future issues of FLS. All of the contributions published here were read and considered by members of the Editorial Board. We thank our authors, referees, reviewers and the production staff for making it possible to bring you this issue.

\section{References}

Albertyn, Catherine. 2014. Judicial diversity. In The judiciary in South Africa, ed. Cora Hoexter and Morné Olivier, 245-287. Cape Town: Juta.

Baldassar, Loretta, and Laura Merla (eds.). 2014. Transnational families, migration and the circulation of care: Understanding mobility and absence in family life. New York: Routledge.

Bonthuys, Elsje. 2015. Gender and race in judicial appointments in South Africa. Feminist Legal Studies 23(2). doi:10.1007/s10691-015-9285-5.

Buss, Doris. 2009. Rethinking 'rape as a weapon of war'. Feminist Legal Studies 17(2): 145-163. doi:10. 1007/s10691-009-9118-5.

Cooper, Davina, and Didi Herman. 2013. Up against the property logic of equality law. Feminist Legal Studies 21(1): 61-80. doi:10.1007/s10691-013-9230-4.

Conaghan, Joanne, and Yvette Russell. 2015. Talking law and gender. Feminist Legal Studies 23(2). doi:10.1007/s10691-015-9288-2.

Darian Smith, Eve. 2015. Global studies-The handmaid of neoliberalism? Globalizations 12(2): 164-168. doi:10.1080/14747731.2014.954775.

Davis, Angela. 1981. Women, race, class. New York: Random House.

Dimova, Margarita, Carrie Hough, Kerry Kyaa, and Ambreena Manji. 2015. Intimacy and inequality: Local care chains and paid childcare in Kenya. Feminist Legal Studies 23(2). doi:10.1007/s10691015-9284-6.

Douglas, Stacy, Suhraiya Jivraj, and Sarah Lamble. 2011. Liabilities of queer anti-racist critique. Feminist Legal Studies 19(2): 107-118. doi:10.1007/s10691-011-9181-6. 
Fudge, Judy. 2014. Feminist reflections on the scope of labour law: Domestic work, social reproduction, and jurisdiction. Feminist Legal Studies 22(1):1-23 http://link.springer.com/article/10.1007/s10691014-9256-2.

Grewal, Inderpal, and Caren Kaplan (eds.). 1994. Scattered hegemonies: Postmodernity and transnational feminist practices. Minneapolis: University of Minnesota Press.

Grewal, Kiran Kaur. 2015. International criminal law as a site for women's rights? challenges, possibilities, strategies. Feminist Legal Studies 23(2). doi:10.1007/s10691-015-9286-4.

Haqqani, Shehnaz. 2015. Review of Ayesha S. Chaudhry. 2013. Domestic violence and the Islamic tradition. Oxford: Oxford University Press. Feminist Legal Studies 23(2). doi:10.1007/s10691-0159276-6.

Keenan, Sarah. 2010. Subversive property: Reshaping malleable spaces of belonging. Social and Legal Studies 19(4): 423-439. doi:10.1177/0964663910372175.

Kuovo, Sari, and Zoe Pearson (eds.). 2011. Feminist perspectives on contemporary international law: Beyond resistance and compliance. Oxford: Hart.

Lemaitre, Julieta, and Kristin Bergtora Sandvik. 2014. Beyond sexual violence in transitional justice: Political insecurity as a gendered harm. Feminist Legal Studies 22(3): 243-261. doi:10.1007/ s10691-014-9274-0.

Monk, Daniel. 2011. Sexuality and succession law: Beyond formal equality. Feminist Legal Studies 19(3): 231-250. doi:10.1007/s10691-011-9188-z.

Mouthaan, Solange. 2015. Review of Gina Heathcote and Dianne Otto (eds.) Rethinking peacekeeping, gender equality and collective security. 2014. Basingstoke: Palgrave Macmillan. Feminist Legal Studies 23(2). doi:10.1007/s10691-015-9289-1.

Odogwu, Will. 2015. Review of Davina Cooper. 2014. Everyday utopias: The conceptual life of promising spaces. Durham: Duke University Press. Feminist Legal Studies 23(2). doi:10.1007/ s10691-014-9272-2.

Otto, Dianne. 1999. Sexualities and solidarities: Some thoughts on coalitional strategies in the context of international law. Australasian Gay and Lesbian Law Journal 8: 27-38.

Rajagopal, Balakrishnan. 2002. International law and social movements: Challenges of theorizing resistance. Columbia Journal of Transnational Law 41: 397-433.

Smart, Carol. 2007. Same sex couples and marriage: Negotiating relational landscapes with families and friends. The Sociological Review 55(4): 671-686.

Stewart, Ann. 2011. Gender, law and justice in a global market. Cambridge: Cambridge University Press.

Thomas, Anisha. 2015. Review of Juliet Rogers. 2013. Law's cut on the body of human rights. New York: Routledge. Feminist Legal Studies 23(2). doi:10.1007/s10691-015-9282-8.

Westwood, Sue. 2015. Complicating kinship and inheritance: Older Lesbians' and Gay Men's Willwriting in England. Feminist Legal Studies 23(2). doi:10.1007/s10691-015-9287-3.

Willmington, Lizzy. 2015. Review of Sara Ahmed. 2014. Willful Subjects. Durham: Duke University Press. Feminist Legal Studies 23(2). doi:10.1007/s10691-015-9290-8. 